LISTY DO REDAKCJI

\title{
A bizarre presentation of dermatitis artefacta
}

\section{Niezwykły obraz dermatitis artefacta}

Przegl Dermatol 2016, 103, 254-255

DOI: 10.5 | | $4 / \mathrm{dr} .2016 .60633$
Dermatitis artefacta (DA), also known as factitious dermatitis, is a psychocutaneous disorder in which the patient self-inflicts the lesions in the skin to fulfill an unconscious psychological need [1, 2]. It is a diagnostic and therapeutic challenge owing to the extremely variable clinical presentation as well as the patient's denial. We report an interesting case of a patient with DA who presented with torn undergarments, relating those tears to some mysterious discharge from underlying skin lesions.

A 65-year-old man presented with a bag containing several torn undergarments (Figure 1). The patient attributed these tears to the results of a discharge from the skin. Examination showed multiple, linear, erythematous to purpuric, well-defined macules with cauterized appearance and erosions over the anterolateral aspect of the right thigh (Figure 2) corresponding to the tears in the undergarments. The general physical and systemic examination was unremarkable. Further interrogation revealed a history of two similar episodes during the last 1.5 months. The lesions used to heal spontaneously over a period of 4-5 days with mild hyperpigmentation (Figure 2). There was no history of skin disease in the past. A tentative diagnosis of dermatitis artefacta was made. The patient was treated with a corticosteroid-antibiotic cream and advised to report back as soon the lesion recurred. The patient returned after

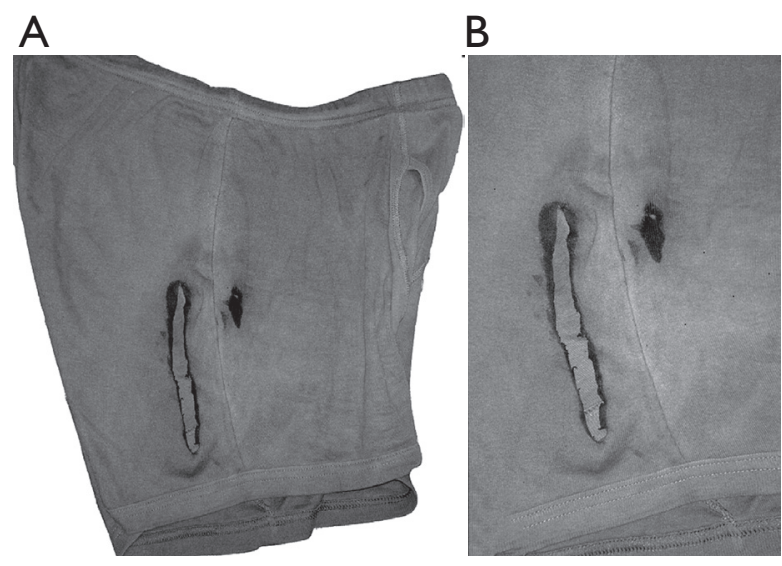

Figure I. Torn undergarment brought by the patient (A). Close up view of the same garment showing two tears (B)

Rycina I. Podziurawiona bielizna przyniesiona przez pacjenta (A). Ta sama bielizna w zbliżeniu z 2 dziurami (B)
10 days with another torn undergarment but without any new skin lesion. On interrogation, his wife and son disclosed that the patient was overstressed due to his business matters and had a financial dispute with his younger brother. The episodes of skin lesions and torn garments occurred during periods of stress and insomnia. Samples of torn garments when sent for chemical analysis showed the $\mathrm{pH}$ between 3 and 4. Psychiatric evaluation revealed the patient to have an attention seeking behavior and obsessive compulsive disorder with depression. The patient was started on antidepressants and sedatives, after which he did not report back to us.

In DA, the patient injures his skin and produces bizarre lesions to satisfy his psychological needs. The

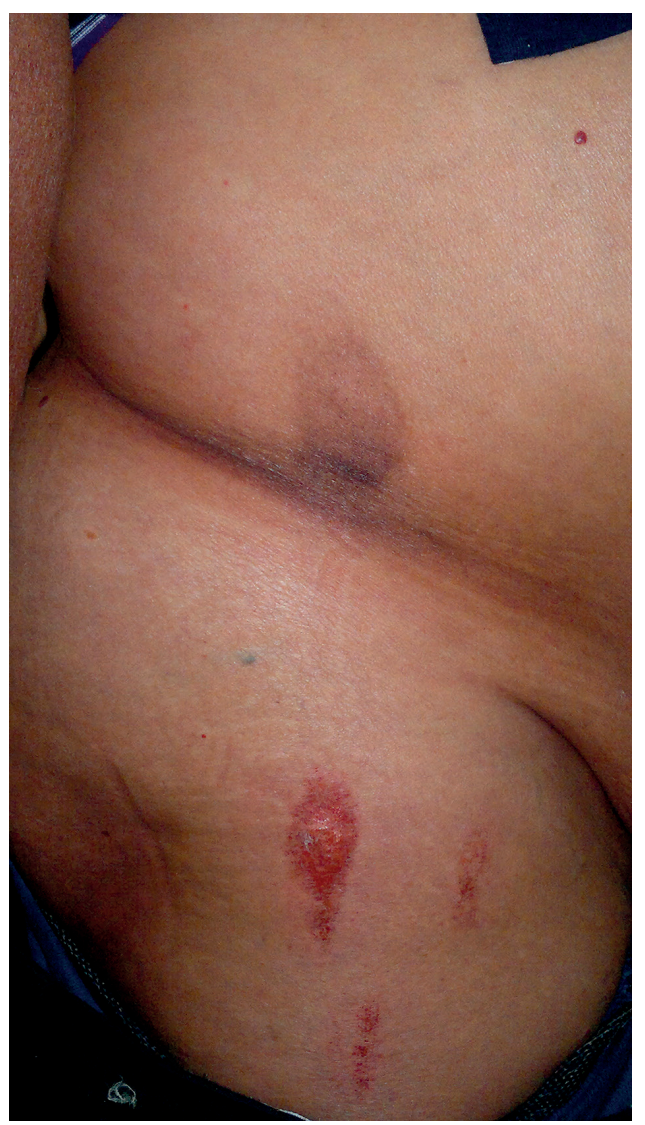

Figure 2. Lesions over thigh and postinflammatory hyperpigmentation at site of previous healed lesions

Rycina 2. Zmiany na udzie i pozapalne przebarwienia w miejscu poprzednich wyleczonych zmian 
condition waxes and wanes according to the fluctuating situations in life [3]. On psychiatric evaluation, patients are found to be emotionally immature or have psychosocial or interpersonal difficulty [4]. The skin lesions enable the patient to express one's agony in a silent, non-verbal manner; therefore they are sometimes called a 'cry for help' or 'focal suicide' [4, 5].

The diagnosis of DA is difficult in most cases, firstly because of the patient's denial of inflicting the lesions and secondly due to highly variable morphology leading to a large number of differential diagnoses, all of which need to be ruled out before labeling a patient as a case of DA. Often the patient presents with a vague history and cannot describe the onset and progression of lesions in a satisfactory way, which is also termed a 'hollow history' $[2,5]$. A high index of suspicion is therefore required. Our patient had attention seeking behavior and obsessive compulsive disorder with depression. The injury to the skin was probably inflicted by using some acidic material, which was revealed on biochemical analysis of

Submitted: 5 IV 2016

Accepted: 30 VI 2016 torn undergarments. To the best of our knowledge, this bizarre and interesting presentation of DA has not been reported previously. The present case is being highlighted in view of its strange and interesting presentation.

\section{CONFLICT OF INTEREST}

The authors declare no conflict of interest.

\section{References}

1. Kumaresan M., Rai R., Raj A.: Dermatitis artefacta. Indian Dermatol Online J 2012, 3, 141-143.

2. Wong J.W., Nguyen T.V., Koo J.Y.: Primary psychiatric conditions: dermatitis artefacta, trichotillomania and neurotic excoriations. Indian J Dermatol 2013, 58, 44-48.

3. Tamakuwala B., Shah P., Dave K., Mehta R.: Dermatitis artefacta. Indian J Psychiatry 2005, 47, 233-234.

4. Nayak S., Acharjya B., Debi B., Swain S.P.: Dermatitis artefacta. Indian J Psychiatry 2013, 55, 189-191.

5. Rodríguez P.A., García B.B.: Dermatitis artefacta: a review. Actas Dermosifiliogr 2013, 104, 854-866.

Ashok Kumar Khare, Ankita Srivastava, Lalit Kumar Gupta, Asit Mittal, Manisha Balai, Sharad Mehta RNT Medical College, Udaipur, India 